\title{
Evaluation of the properties of a foamed geopolymer developed with different types of metakaolin
}

\author{
R.T.Lermen ${ }^{1 *}$, E.M. Korf ${ }^{1}$, L. N. de Oliveira ${ }^{1}$, R. N. de Oliveira ${ }^{1}$, \\ D. D. dos Santos Neto ${ }^{I}, R$. Ferreira Júnior ${ }^{l}, R$. A. Silva ${ }^{1}$ \\ ${ }^{l} I M E D$, School of Engineering and Applied Sciences, Postgraduation Program of Civil Engineering, \\ Passo Fundo, Brazil
}

\begin{abstract}
The physical and mechanical properties of foamed geopolymers were determined. The geopolymers were made with two different metakaolins (from Metacaulim do Brasil - MB, and Pantano Grande/RS - MPG) as precursors, with $\mathrm{NaOH}$ and $\mathrm{Na}_{2} \mathrm{SiO}_{3}$ as activators, and with the addition of foam, which was produced with the foaming agent diethanolamide of coconut fatty acid with a minimum of $80 \%$ concentration. Also, two times $(2.5$ and $4 \mathrm{~h})$ were used for the calcination of MPG at $750{ }^{\circ} \mathrm{C}$. The results showed that all factors (precursors type, alkali content, silica modulus, and foam content) had a significant influence on the response variables, which presented the following variations: compressive strength of 0.36 to $3.23 \mathrm{MPa}$; thermal conductivity from 0.22 to $0.42 \mathrm{~W} /(\mathrm{m} . \mathrm{K})$; saturated bulk density from 1176 to $1364 \mathrm{~kg} / \mathrm{m}^{3}$; dry bulk density of 619 to $864 \mathrm{~kg} / \mathrm{m}^{3}$; air void from $46.4 \%$ to $62.5 \%$; and water absorption from $55.7 \%$ to $95.4 \%$. It was also concluded that the precursor type was the factor that had the most influence on the properties of foamed geopolymers, with MPG calcined for $4 \mathrm{~h}$ being the best, as greater compressive strength and low thermal conductivity were obtained.
\end{abstract}

Keywords: foamed geopolymer, metakaolin, amide 80, thermal conductivity, compressive strength, density.

\section{INTRODUCTION}

Over the past few years, Portland cement concrete has been the product of the greatest volume manufactured on the planet. The low-cost and availability of raw materials and processing technologies, combined with its wide versatility and good performance, are the main reasons and advantages for the high consumption of concrete developed with Portland cement. However, due to worldwide concern about sustainability, the cement industry is facing strong pressure as Portland cement production is being perceived as unsustainable and ecologically incorrect [1]. This environmental pressure occurs mainly due to the emission of gases which are responsible for the greenhouse effect and the large consumption of energy in the calcination of clinker, which occurs at high temperatures (approximately $1400^{\circ} \mathrm{C}$ ). In addition, to meet global demand, the large volumes of Portland cement produced lead to high consumption of raw materials and dust pollution $[2,3]$. Thus, the development of new materials plays a major role in increasing sustainable construction, as the aim of using such materials is to reduce energy consumption, the emission of pollutants, and the production of wastes [4]. As an alternative to the issues mentioned, geopolymers have come to the fore. These are binding agents produced from an aluminosilicate, which hardens at room temperature, in a relatively short period of time (between 2 and 48 h) [5, 6]. Geopolymers are usually produced by combining a precursor material (e.g., metakaolin or fly ash) with a highly alkaline chemical

*richard.lermen@gmail.com

(Dhttps://orcid.org/0000-0003-2335-9481 reagent (activator) [7-9]. They are innovative materials that are being studied for a number of applications, including fiber-reinforced composites [10-12], refractory composites (aerated geopolymers) [13], precursors for the formation of ceramics [14-16], and waste adsorption [17]. Environmentally, these materials reduce $\mathrm{CO}_{2}$ emission rates, compared to those of Portland cement, as they do not use the clinker process, thereby reducing energy consumption $[9,18]$.

The geopolymers used as refractory materials have pores in their structure that are generated by different mechanisms. These porous polymeric materials have low thermal conductivities, which resist high temperatures, low densities, and are also good acoustic insulators [19]. In this context, according to Kumar [20], few studies have been carried out with porous geopolymers developed with the addition of foam, which can be an alternative to replace foamed cellular concretes in civil construction. The vast majority of research studies use aluminum powder and hydrogen peroxide $\left(\mathrm{H}_{2} \mathrm{O}_{2}\right)$ as pore-forming agents and fly ash as a precursor [19, 21-24]. Su et al. [25] studied a foamed fly ash geopolymer where fly ash was activated by sodium silicate solution, and an aluminum powder was employed as an in situ chemical foaming agent. For densities from 1200 to $600 \mathrm{~kg} / \mathrm{m}^{3}$, the thermal conductivity diminished from 0.70 to $0.22 \mathrm{~W} /(\mathrm{m} . \mathrm{K})$, which is much better than that of its counterpart, ordinary Portland cement. Phavongkham et al. [26] evaluated the effects of surfactant on thermo-mechanical behavior of geopolymer foam paste made with sodium perborate foaming agent. All foamed geopolymers prepared with and without the surfactant showed 28 day-curing compressive strength in the range of 4.21 to $4.82 \mathrm{MPa}$ with improvement 
when the surfactant was added and thermal conductivity was in the range of 0.27 to $0.32 \mathrm{~W} /(\mathrm{m} . \mathrm{K})$. Masi et al. [24] used fly ash as a precursor and three different foaming agents: aluminum powder, $\mathrm{H}_{2} \mathrm{O}_{2}$, and surfactant $(40 \mathrm{wt} \%$ solution of fatty acid, amide, and sodium salt of $\mathrm{C}_{14}{ }^{-} \mathrm{C}_{16}$ sulphonic acid in water). These foaming agents were added to the geopolymer pastes separately and mixed. Homogeneous microstructures with small pores were obtained by adding surfactant and $\mathrm{H}_{2} \mathrm{O}_{2}$. The combination of hydrogen peroxide $(0.1 \mathrm{wt} \%)$ and surfactant (1.0 wt \%) produced foamed geopolymers with density and compressive strength values of $940 \mathrm{~kg} / \mathrm{m}^{3}$ and $4.6 \mathrm{MPa}$, respectively. Abdullah et al. [27] used superplasticizer as a foaming agent and also fly ash as a precursor. For foamed geopolymers, high compressive strengths were obtained after 28 days, around $18 \mathrm{MPa}$. The pores were homogeneously distributed in the geopolymeric matrix with small diameters, from 4 to $37 \mu \mathrm{m}$.

In general, there is still much to be explored with regard to foamed geopolymers, and no work has been developed using amide 80 as a foaming agent and metakaolins from Metacaulim do Brasil or from Southern Brazil (Pantano Grande/RS) as precursors. So, the main objective of this paper is to evaluate the physical and mechanical properties of foamed geopolymers that were developed based on different metakaolins and amide 80 as a foaming agent.

\section{EXPERIMENTAL}

Materials: Fig. 1 shows the precursor materials used in the production of foamed geopolymers. A kaolin sample (Fig. 1a) was obtained from the reserve in Pantano Grande-RS, Brazil, and calcined for 2.5 and $4 \mathrm{~h}$ at $750{ }^{\circ} \mathrm{C}$, thereby generating two types of precursor: metakaolin calcined for $2.5 \mathrm{~h}-\mathrm{MPG} 2.5$ (Fig. 1b); and metakaolin calcined for $4 \mathrm{~h}$ - MPG4 (Fig. 1c). The kaolin was calcined in a Romatex muffle and, sequentially, the samples were ground using a ball mill and sieved through a 200 mesh sieve, following the methodology used by Longhi [28]. Also, a commercial metakaolin (HP Ultra, Metacaulim do Brasil) - MB (Fig. 1d), was used as a precursor. The foaming agent used in the production of foam was amide 80 ( $80 \%$ fatty acid diethanolamide, Quimicamar). A mechanical stirrer was used to produce a foam with a density of $75 \mathrm{~kg} / \mathrm{m}^{3}$ (Fig. 2a), in which, it was considered that $98 \%$ was $\mathrm{H}_{2} \mathrm{O}$. As alkaline activators, sodium silicate $\left(\mathrm{Na}_{2} \mathrm{SiO}_{3}\right.$, Nilla, Fig. 2 b), with $53 \% \mathrm{H}_{2} \mathrm{O}, 15 \% \mathrm{Na}_{2} \mathrm{O}$, and $32 \% \mathrm{SiO}_{2}$, and $\mathrm{SiO}_{2} / \mathrm{Na}_{2} \mathrm{O}$ ratio of 2.14 , and scaled sodium hydroxide $(\mathrm{NaOH} 99 \%$, Buschle \& Lepper, Fig. 2c) were used.

The major oxides in the precursors were determined by $\mathrm{X}$-ray fluorescence spectrometry (XRF) carried out with a spectrometer (MiniPal 4, PanAlytical). Table I shows the chemical compositions obtained for the metakaolins. The $\mathrm{SiO}_{2} / \mathrm{Al}_{2} \mathrm{O}_{3}$ total molar ratio is also of great importance in alkali binder activation. According to Komnitsas and Zaharaki [29], when there is an increase in $\mathrm{Al}_{2} \mathrm{O}_{3}$ content, the $\mathrm{SiO} / \mathrm{Al}_{2} \mathrm{O}_{3}$ ratio decreases and the resulting products have lower mechanical resistance. Duxson et al. [9] also demonstrated that $\mathrm{SiO}_{2} / \mathrm{Al}_{2} \mathrm{O}_{3}$ ratios below 1.4 generate pastes with large, interconnected pores. Samples with a ratio greater than 1.65 may have small distributed pores. The crystalline phases of the samples were identified by X-ray diffraction (XRD) analysis, performed with a diffractometer (X' pert PRO Multi-Purpose, PanAlytical) using $\mathrm{CuK} \alpha$ radiation $(\lambda=1.5418$ $\AA$ ) at $40 \mathrm{kV}$ and $30 \mathrm{~mA}$ and irradiations varying from 0 to $90^{\circ}$ $(2 \theta)$, with an interval of $0.05^{\circ}$ for each $1 \mathrm{~s}$. Fig. 3 shows the $\mathrm{X}$-ray diffractograms of the kaolin, MPG2.5, MPG4, and MB, respectively. Amounts of crystalline and amorphous phases were determined using the Rietveld method [30-32]. Fig. 3a shows the diffractogram for kaolin in natura, which had the same crystalline phases (kaolinite, phengite, muscovite, and quartz) as the calcined samples, but with greater crystallinity. The kaolin from Pantano Grande calcined for $2.5 \mathrm{~h}$ (metakaolin MPG2.5, Fig. 3b) showed $85.10 \%$ of amorphism and kaolin
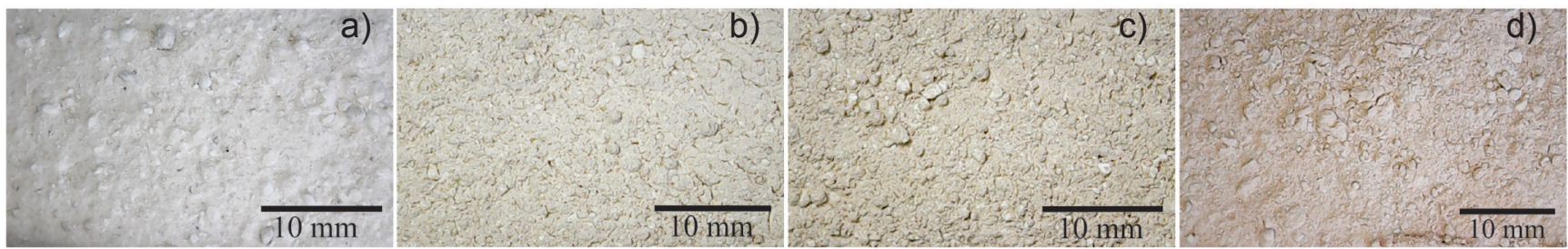

Figure 1: Images of: a) kaolin from Pantano Grande/RS; and metakaolins used in the production of foamed geopolymers: b) MPG2.5; c) MPG4; and d) MB.
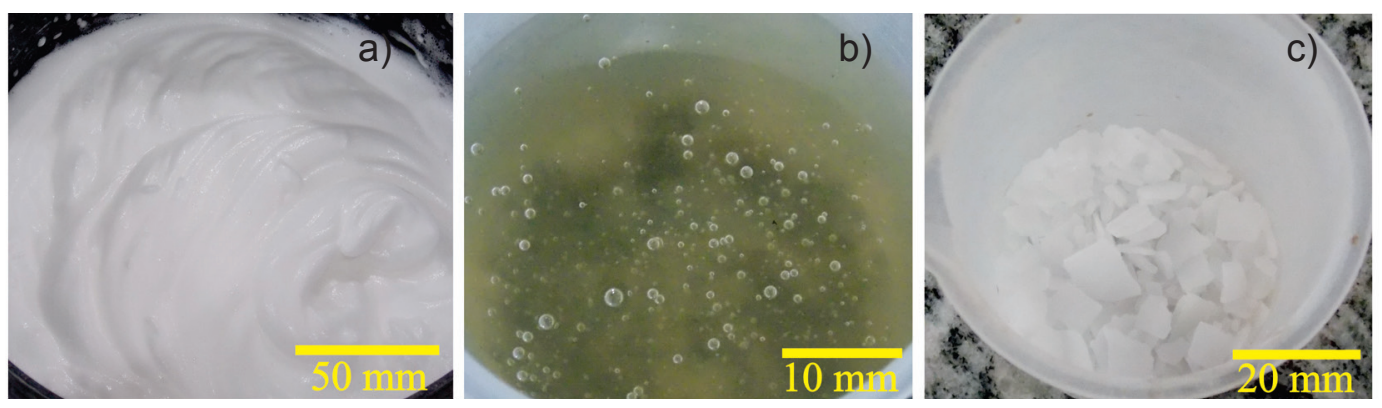

Figure 2: Images of: a) foam formed from amide 80; b) sodium silicate; and c) $\mathrm{NaOH}$ flakes. 
Table I - Chemical compositions by XRF for metakaolin samples.

\begin{tabular}{ccccccccccccc}
\hline Sample & $\mathrm{SiO}_{2}$ & $\mathrm{Al}_{2} \mathrm{O}_{3}$ & $\mathrm{TiO}_{2}$ & $\mathrm{Fe}_{2} \mathrm{O}_{3}$ & $\mathrm{MnO}$ & $\mathrm{MgO}$ & $\mathrm{SO}_{3}$ & $\mathrm{ZrO}_{2}$ & $\mathrm{~K}_{2} \mathrm{O}$ & $\mathrm{P}_{2} \mathrm{O}_{5}$ & LOI & Total \\
\hline $\mathrm{MB}$ & 65.57 & 25.77 & 1.49 & 4.10 & 0.01 & 0.51 & 0.12 & 0.12 & 2.13 & 0.03 & 0.15 & 100 \\
$\mathrm{MPG}$ & 59.09 & 37.47 & 0.13 & 1.26 & 0.01 & 0.06 & nd & nd & 0.77 & nd & 1.21 & 100 \\
\hline
\end{tabular}

LOI - loss on ignition; $n d$ - not detected; MB - metakaolin HP Ultra; MPG - metakaolin from Pantano Grande.
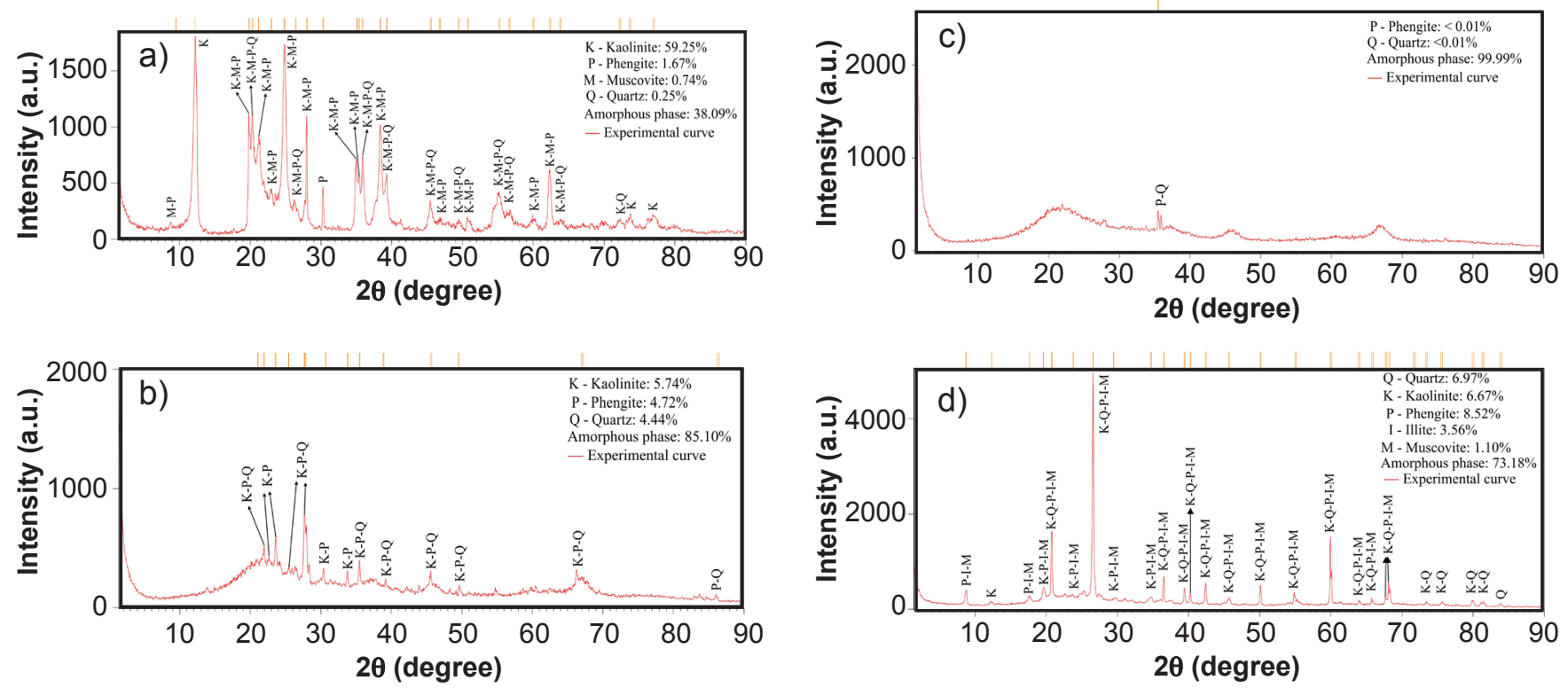

Figure 3: XRD patterns of: a) kaolin from Pantano Grande-RS; b) kaolin calcined for $2.5 \mathrm{~h}$ at $750{ }^{\circ} \mathrm{C}-\mathrm{MPG} 2.5$; c) kaolin calcined for $4 \mathrm{~h}$ at $750{ }^{\circ} \mathrm{C}$ - MPG4; and d) metakaolin HP Ultra - MB.
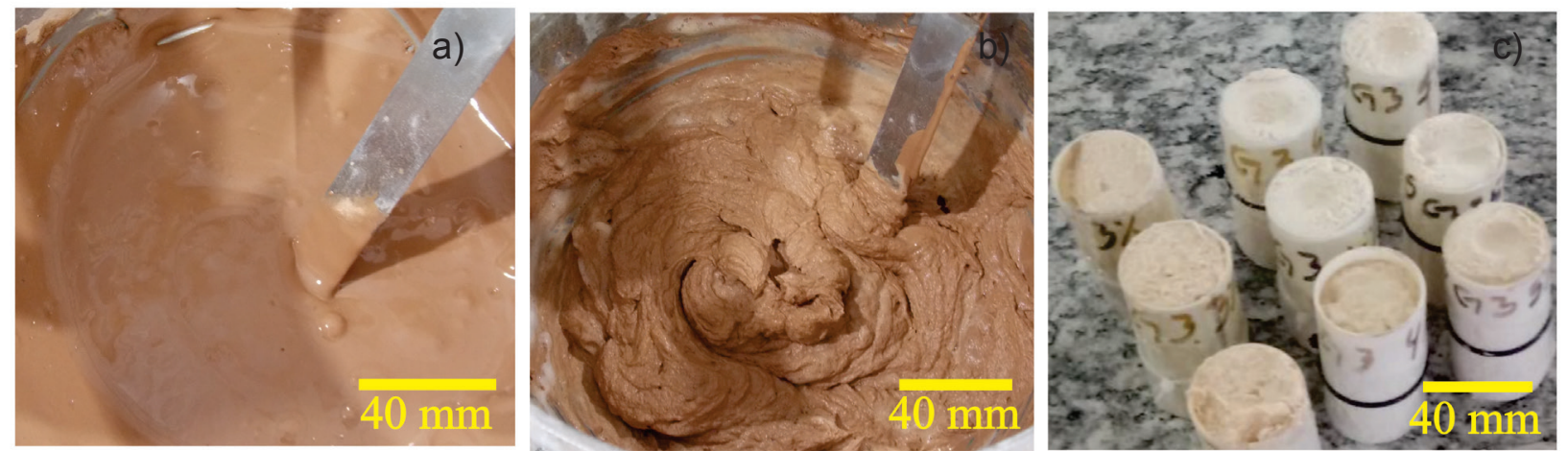

Figure 4: Images showing MB geopolymer paste without (a) and with foam (b), and molded cylindrical specimens (c).

calcined for $4 \mathrm{~h}$ (metakaolin MPG4, Fig. 3c) showed 99.99\% of the amorphous phase. For MB (Fig. 3d), 73.18\% amorphous phase was found and crystalline phases observed were muscovite $\left[\mathrm{KAl}_{2}\left(\mathrm{Si}_{3} \mathrm{Al}\right) \mathrm{O}_{10}(\mathrm{OH}, \mathrm{F})_{2}\right]$, kaolinite $\left[\mathrm{Al}_{2} \mathrm{Si}_{2} \mathrm{O}_{5}(\mathrm{OH})_{4}\right]$, quartz $\left(\mathrm{SiO}_{2}\right)$, illite $\left\{\left(\mathrm{K}, \mathrm{H}_{3} \mathrm{O}\right)(\mathrm{Al}, \mathrm{Mg}, \mathrm{Fe})_{2}(\mathrm{Si}, \mathrm{Al})_{4} \mathrm{O}_{10}\left[(\mathrm{OH})_{2}, \mathrm{H}_{2} \mathrm{O}\right]\right\}$ and phengite $\left[\mathrm{K}(\mathrm{Al}, \mathrm{Mg})_{2}(\mathrm{OH})_{2}(\mathrm{Si}, \mathrm{Al})_{4} \mathrm{O}_{10}\right]$. The characteristic peaks of quartz and kaolinite indicated the presence of impurities and incomplete calcination. According to Longhi [28], the greater the amorphism of metakaolin, the greater the reactivity, i.e. the greater amount of active silica is formed to dissolve in an alkaline medium.

Synthesis of foamed geopolymer: the specimens were initially made by weighing the materials and dissolving the flakes of sodium hydroxide in water. Due to the increase in temperature because of the exothermic reaction, this solution remained at rest for $24 \mathrm{~h}$ until it reached room temperature, approximately $25{ }^{\circ} \mathrm{C}$. Then sodium silicate was added to the solution. In the next step, the precursor was added to the solution $\left(\mathrm{NaOH}+\mathrm{Na}_{2} \mathrm{SiO}_{3}\right)$ and held in a mechanical mortar mixer, thereby forming a geopolymer paste (Fig. 4a). This paste was mixed for $5 \mathrm{~min}$ at a speed of $140 \mathrm{rpm}$ until its homogenization, and then, the foam was added. This mixture was then mixed for another $5 \mathrm{~min}$ at a speed of $240 \mathrm{rpm}$, thus forming the foamed geopolymer (Fig. 4b). Then, cylindrical specimens (Fig. 4c) with dimensions of $40 \mathrm{~mm}$ in diameter and $80 \mathrm{~mm}$ in height were molded. They were subjected to curing at room temperature (approximately $20^{\circ} \mathrm{C}$ ) for a period of 28 days for the complete geopolymerization of 
the material. Rectangular specimens were also molded for the thermal conductivity assay, with dimensions of $100 \mathrm{~mm}$ wide by $300 \mathrm{~mm}$ long and $30 \mathrm{~mm}$ high. After curing, tests were conducted to determine the physical and mechanical properties of the specimens.

Characterization of the foamed geopolymer: the specimens

Table II - Experimental matrix.

\begin{tabular}{|c|c|c|c|c|c|c|c|c|c|c|c|c|}
\hline \multirow[b]{2}{*}{ Run } & \multirow[b]{2}{*}{ MK type } & \multirow[b]{2}{*}{$\begin{array}{c}\text { MK } \\
(\mathrm{g})\end{array}$} & \multirow[b]{2}{*}{$\begin{array}{l}\text { SS } \\
(\mathrm{g})\end{array}$} & \multirow[b]{2}{*}{$\begin{array}{c}\mathrm{NaOH} \\
(\mathrm{g})\end{array}$} & \multirow[b]{2}{*}{$\begin{array}{l}\text { FC } \\
(\mathrm{g})\end{array}$} & \multirow[b]{2}{*}{$\begin{array}{c}\mathrm{H}_{2} \mathrm{O} \\
(\mathrm{g})\end{array}$} & \multicolumn{2}{|c|}{ Activator } & \multicolumn{4}{|c|}{ Total molar ratio } \\
\hline & & & & & & & SM & $\begin{array}{c}\% \\
\text { alkali } \\
\end{array}$ & $\begin{array}{l}\mathrm{SiO}_{2} / \\
\mathrm{Al}_{2} \mathrm{O}_{3}\end{array}$ & $\begin{array}{l}\mathrm{Na}_{2} \mathrm{O} / \\
\mathrm{Al}_{2} \mathrm{O}_{3}\end{array}$ & $\begin{array}{l}\mathrm{H}_{2} \mathrm{O} / \\
\mathrm{Na}_{2} \mathrm{O}\end{array}$ & $\begin{array}{c}\mathrm{Na}_{2} \mathrm{O} / \\
\mathrm{SiO}_{2} \\
\end{array}$ \\
\hline 1 & MB & 100 & 24.73 & 14.66 & 3.44 & 48.23 & 0.5 & 15 & 3.37 & 0.88 & 14.77 & 0.26 \\
\hline 2 & MB & 100 & 24.73 & 14.66 & 4.59 & 47.10 & 0.5 & 15 & 3.37 & 0.88 & 14.51 & 0.26 \\
\hline 3 & MB & 100 & 24.73 & 14.66 & 5.73 & 45.98 & 0.5 & 15 & 3.37 & 0.88 & 14.25 & 0.26 \\
\hline 4 & MB & 100 & 49.46 & 9.97 & 3.30 & 46.26 & 1.0 & 15 & 3.85 & 0.89 & 16.99 & 0.23 \\
\hline 5 & MB & 100 & 49.46 & 9.97 & 4.40 & 45.18 & 1.0 & 15 & 3.85 & 0.89 & 16.74 & 0.23 \\
\hline 6 & MB & 100 & 49.46 & 9.97 & 5.50 & 44.10 & 1.0 & 15 & 3.85 & 0.89 & 16.50 & 0.23 \\
\hline 7 & MB & 100 & 32.97 & 19.55 & 3.59 & 50.28 & 0.5 & 20 & 3.53 & 1.17 & 12.36 & 0.33 \\
\hline 8 & MB & 100 & 32.97 & 19.55 & 4.78 & 49.11 & 0.5 & 20 & 3.53 & 1.17 & 12.16 & 0.33 \\
\hline 9 & MB & 100 & 32.97 & 19.55 & 5.98 & 47.94 & 0.5 & 20 & 3.53 & 1.17 & 11.96 & 0.33 \\
\hline 10 & MB & 100 & 65.94 & 13.30 & 3.40 & 47.65 & 1.0 & 20 & 4.17 & 1.18 & 14.59 & 0.28 \\
\hline 11 & MB & 100 & 65.94 & 13.30 & 4.53 & 46.54 & 1.0 & 20 & 4.17 & 1.18 & 14.40 & 0.28 \\
\hline 12 & MB & 100 & 65.94 & 13.30 & 5.66 & 45.43 & 1.0 & 20 & 4.17 & 1.18 & 14.21 & 0.28 \\
\hline 13 & MPG2.5 & 100 & 24.73 & 14.66 & 3.44 & 48.23 & 0.5 & 15 & 2.61 & 0.65 & 14.77 & 0.25 \\
\hline 14 & MPG2.5 & 100 & 24.73 & 14.66 & 4.59 & 47.10 & 0.5 & 15 & 2.61 & 0.65 & 14.51 & 0.25 \\
\hline 15 & MPG2.5 & 100 & 24.73 & 14.66 & 5.73 & 45.98 & 0.5 & 15 & 2.61 & 0.65 & 14.25 & 0.25 \\
\hline 16 & MPG2.5 & 100 & 49.46 & 9.97 & 3.30 & 46.26 & 1.0 & 15 & 2.96 & 0.66 & 16.99 & 0.22 \\
\hline 17 & MPG2.5 & 100 & 49.46 & 9.97 & 4.40 & 45.18 & 1.0 & 15 & 2.96 & 0.66 & 16.74 & 0.22 \\
\hline 18 & MPG2.5 & 100 & 49.46 & 9.97 & 5.50 & 44.10 & 1.0 & 15 & 2.96 & 0.66 & 16.50 & 0.22 \\
\hline 19 & MPG2.5 & 100 & 32.97 & 19.55 & 3.59 & 50.28 & 0.5 & 20 & 2.72 & 0.87 & 12.36 & 0.32 \\
\hline 20 & MPG2.5 & 100 & 32.97 & 19.55 & 4.78 & 49.11 & 0.5 & 20 & 2.72 & 0.87 & 12.16 & 0.32 \\
\hline 21 & MPG2.5 & 100 & 32.97 & 19.55 & 5.98 & 47.94 & 0.5 & 20 & 2.72 & 0.87 & 11.96 & 0.32 \\
\hline 22 & MPG2.5 & 100 & 65.94 & 13.30 & 3.40 & 47.65 & 1.0 & 20 & 3.20 & 0.88 & 14.59 & 0.27 \\
\hline 23 & MPG2.5 & 100 & 65.94 & 13.30 & 4.53 & 46.54 & 1.0 & 20 & 3.20 & 0.88 & 14.40 & 0.27 \\
\hline 24 & MPG2.5 & 100 & 65.94 & 13.30 & 5.66 & 45.43 & 1.0 & 20 & 3.20 & 0.88 & 14.21 & 0.27 \\
\hline 25 & MPG4 & 100 & 24.73 & 14.66 & 3.44 & 48.23 & 0.5 & 15 & 3.00 & 0.65 & 14.77 & 0.22 \\
\hline 26 & MPG4 & 100 & 24.73 & 14.66 & 4.59 & 47.10 & 0.5 & 15 & 3.00 & 0.65 & 14.51 & 0.22 \\
\hline 27 & MPG4 & 100 & 24.73 & 14.66 & 5.73 & 45.98 & 0.5 & 15 & 3.00 & 0.65 & 14.25 & 0.22 \\
\hline 28 & MPG4 & 100 & 49.46 & 9.97 & 3.30 & 46.26 & 1.0 & 15 & 3.35 & 0.66 & 16.99 & 0.20 \\
\hline 29 & MPG4 & 100 & 49.46 & 9.97 & 4.40 & 45.18 & 1.0 & 15 & 3.35 & 0.66 & 16.74 & 0.20 \\
\hline 30 & MPG4 & 100 & 49.46 & 9.97 & 5.50 & 44.10 & 1.0 & 15 & 3.35 & 0.66 & 16.50 & 0.20 \\
\hline 31 & MPG4 & 100 & 32.97 & 19.55 & 3.59 & 50.28 & 0.5 & 20 & 3.12 & 0.87 & 12.36 & 0.28 \\
\hline 32 & MPG4 & 100 & 32.97 & 19.55 & 4.78 & 49.11 & 0.5 & 20 & 3.12 & 0.87 & 12.16 & 0.28 \\
\hline 33 & MPG4 & 100 & 32.97 & 19.55 & 5.98 & 47.94 & 0.5 & 20 & 3.12 & 0.87 & 11.96 & 0.28 \\
\hline 34 & MPG4 & 100 & 65.94 & 13.30 & 3.40 & 47.65 & 1.0 & 20 & 3.59 & 0.88 & 14.59 & 0.24 \\
\hline 35 & MPG4 & 100 & 65.94 & 13.30 & 4.53 & 46.54 & 1.0 & 20 & 3.59 & 0.88 & 14.40 & 0.24 \\
\hline 36 & MPG4 & 100 & 65.94 & 13.30 & 5.66 & 45.43 & 1.0 & 20 & 3.59 & 0.88 & 14.21 & 0.24 \\
\hline
\end{tabular}


were characterized by the following experimental tests: compressive strength; dry and saturated densities; water absorption; air void; and thermal conductivity. The compressive strength test followed the procedures of the Brazilian standard NBR 7215 [33]. Although this standard is intended to test the strength of Portland cement, due to the lack of standardization for geopolymeric materials, the specimens were tested according to this standard. For this test, a mechanical testing machine (PC 200C, Emic) with a capacity of $2000 \mathrm{kN}$, crosshead speed of $0.7 \mathrm{~mm} / \mathrm{min}$, and accuracy of approximately $1 \%$ of the applied load was used. In order to determine the dry and saturated bulk densities, water absorption, and air void (porosity), the procedures of the Brazilian standard NBR 9778 [34] were followed. The analysis technique described in the British standard BS EN 480-11 [35] and by other authors $[24,36,37]$ was used to determine the shape and size of the pores. Two specimens were prepared for each sample, namely, one for the longitudinal section and the other for the crosssection. The specimens were carefully polished, thus avoiding the creation of new pores that would cause measurement errors. The macrographs were obtained with an electronic magnifying glass and analyzed using ImageJ software (National Institutes of Health, USA). Thermal conductivity was determined using the hot wire surface technique. Several authors [38-43] have already corroborated that this technique is a variant of the hot wire parallel technique, which is characterized as being a direct method that detects the transient temperature. Fourier transform infrared spectroscopy (FTIR), using a spectrometer (FTIR-ATR, Perkin Elmer) in absorbance mode from 4000 to $400 \mathrm{~cm}^{-1}$, was performed to verify the possible effects of the chemical composition on the geopolymerization reaction process.

Design of experiments: an experimental design matrix was implemented using the complete factorial methodology with 36 runs as shown in Table II. The experimental design had 4 factors, namely, the type of precursor (metakaolin), the alkali content (\% alkali), the silica modulus (SM), and the foam content (FC). Three types of precursors were used and, consequently, there were 3 levels for this factor (MB, MPG2.5, and MPG4). For the alkali content and silica modulus, two levels were used, i.e. specimens were evaluated with $15 \%$ and $20 \%$ of alkali and 0.5 and 1.0 SM. The factors and levels were chosen according to the literature $[5,8,44]$. For the foam content added to the polymeric paste, 3 levels were used, namely, $3 \%, 4 \%$, and $5 \%$ in relation to the total mass of solids in the mixture. For each assay performed, 3 specimens were produced, totaling 324 specimens. As it is a non-destructive assay, the specimens used in the thermal conductivity test were used for the tests to determine densities (dry and saturated), air void, and water absorption. The solid-water ratio was kept constant at 0.45 ; the amount of water considered was the sum of the water contained in the foam, in the sodium silicate, and the water that was added to dissolve the sodium hydroxide. An analysis of variance (ANOVA) was used to determine the influence of factors on response variables (compressive strength, densities, air void, water absorption, and thermal conductivity). The factors were considered significant for $\mathrm{p}$-values $\leq 0.05$ (critical value adopted), which indicated a confidence level of $\geq 95 \%$ for the mean. In addition, the contribution fraction of each factor was also estimated by the sum of squares. The p-value is a probability that measures the evidence against the null hypothesis, and the lower probabilities provide stronger evidence against the null hypothesis. The F value is the statistical test used to determine whether the term is associated with the response, i.e. the higher the $F$ value, the more influential the factor is in the response [45]. Amorphous phases were also considered for the calculation of the total real molar ratios, i.e., it was considered that only the silica contained in the amorphous phase of the precursor plus the silica of the activator (sodium silicate) were reactive for the synthesis of geopolymers.

\section{RESULTS AND DISCUSSION}

A geopolymeric product formation can be done by evaluating the operational envelope for synthesizing the geopolymers, i.e., by evaluating the ternary diagram of
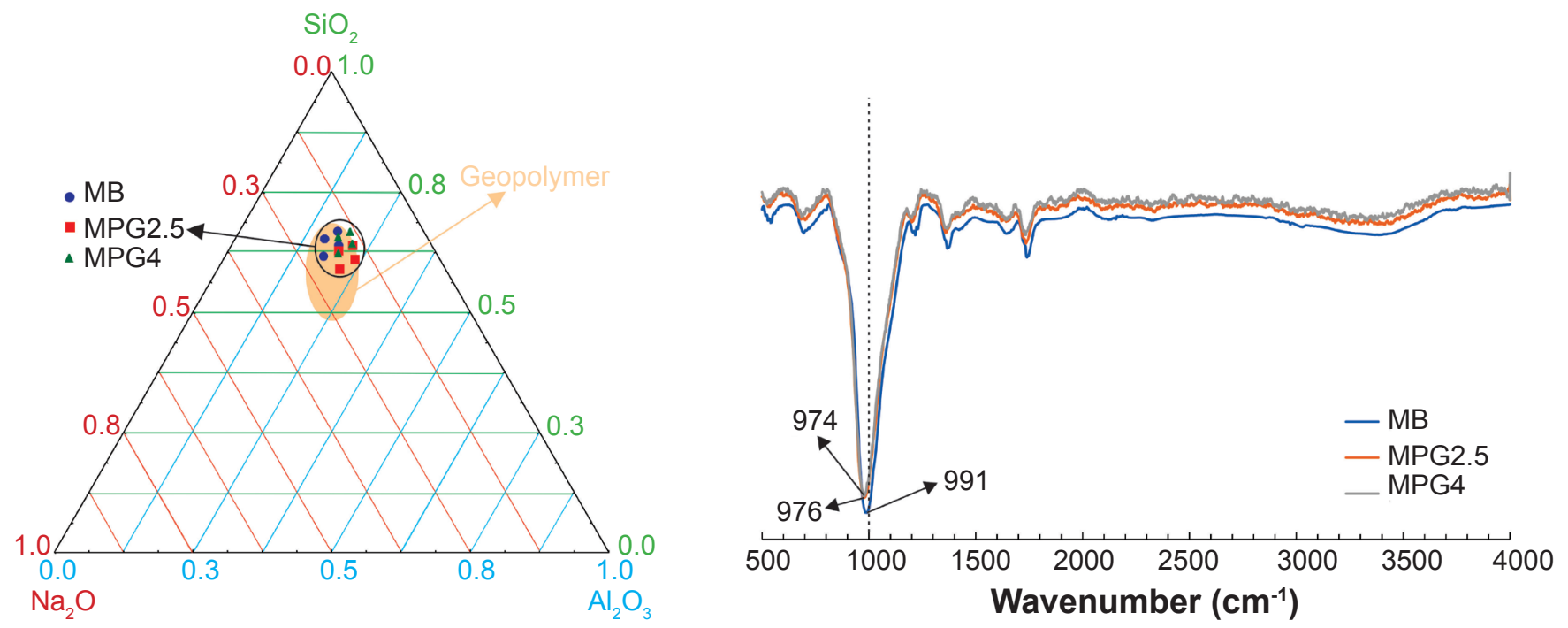

Figure 5: Ternary diagram of $\mathrm{Na}_{2} \mathrm{O}-\mathrm{SiO}_{2}-\mathrm{Al}_{2} \mathrm{O}_{3}$ (adapted from [46]) showing the chemistry of experimental samples and geopolymer formation region (a) and FTIR spectra of geopolymers prepared with MB, MPG2.5, and MPG4, 15\% of alkali content, and 0.5 of silica modulus (b). 
$\mathrm{SiO}_{2}, \mathrm{Na}_{2} \mathrm{O}$, and $\mathrm{Al}_{2} \mathrm{O}_{3}$ (Fig. 5a), it was observed that all the samples produced in the present work were contained in the envelope synthesis of geopolymer described in the literature $[46,47]$. Fig. 5b shows FTIR spectra for geopolymers prepared with MB, MPG2.5, and MPG4, all with $15 \%$ of alkali content and 0.5 of silica modulus. It was identified that the geopolymerization process occurred through the formation of a gel, confirmed by the band between 991 and $974 \mathrm{~cm}^{-1}$ because the degree of geopolymerization through this characteristic band is attributed to the asymmetric stretching of the Si-O-Si and Si-O-Al. The band between 3800 and $3450 \mathrm{~cm}^{-1}$ was due to $\mathrm{O}-\mathrm{H}$ vibrations and the band between 1650 and $1630 \mathrm{~cm}^{-1}$ was due to $\mathrm{H}-\mathrm{O}-\mathrm{H}$ vibrations. These bands indicated the presence of weak bonds of $\mathrm{H}_{2} \mathrm{O}$ molecules, which were absorbed on the surface or trapped in the cavities of the geopolymeric structure. The appearance of peaks between 600 and $800 \mathrm{~cm}^{-1}$ indicated the dissolution of species for the formation of the proper bonds of the geopolymer structure. Results obtained were in accordance with the literature [44, 48-50].

Metakaolin type effect: Fig. 6 shows the graphs of the response variables according to the type of metakaolin, in which the point is equivalent to the average value, the box to the standard deviation, and the whiskers to the confidence interval of 95\%. In Fig. 6a, the relationship can be identified between the compressive strength with the different types of metakaolin, where the point is equivalent to the average compressive strength value. As expected, MPG4 showed greater average compressive strength than MPG2.5, confirming that the difference in strength was related to the calcination process to which each metakaolin was subjected.
In other words, during the calcination process, structural changes of the source material (natural kaolin) occurred, which, among other factors, were influenced by the time of exposure to heat (calcination time). This fact can be better understood when looking at the XRD patterns in Figs. $3 b$ and $3 \mathrm{c}$, which show that the metakaolin calcined for $4 \mathrm{~h}$ had greater amorphism (fewer peaks) than that calcined for $2.5 \mathrm{~h}$. According to Tukey's statistical test, a comparison between the average compressive strengths of MPG4 and MB did not present a difference because the total real molar ratios of oxides were close in these samples. The fact that MB metakaolin resulted in a higher mean strength compared to MPG2.5 was possibly due to the higher $\mathrm{SiO}_{2} / \mathrm{Al}_{2} \mathrm{O}_{3}$ total molar ratio of the paste mixture, as can be seen in the XRF results for the metakaolin samples (Table I). In addition, the sum of $\mathrm{Al}_{2} \mathrm{O}_{3}, \mathrm{Fe}_{2} \mathrm{O}_{3}$, and $\mathrm{K}_{2} \mathrm{O}$ of the metakaolin from Pantano Grande was higher compared to the commercial MB metakaolin. These oxides consumed the alkalinity of the system, which was fundamental to dissolving $\mathrm{SiO}_{2}$ by breaking $\mathrm{Si}-\mathrm{O}-\mathrm{Si}$ bonds and important in forming the geopolymeric gel.

In Fig. 6b, the results of dry density and saturated density can be observed in relation to the different precursors evaluated. It was observed that the specimens made with the precursor MPG2.5 presented lower dry and saturated densities. Comparing the water absorptions and air voids based on the types of precursors used (Figs. $6 \mathrm{c}$ and $6 \mathrm{~d}$, respectively), it was noted a change in these results, in accordance with the metakaolin used. The high contribution of the precursor material may be related to the fact of low polymerization in the specimens made using MPG2.5 as a
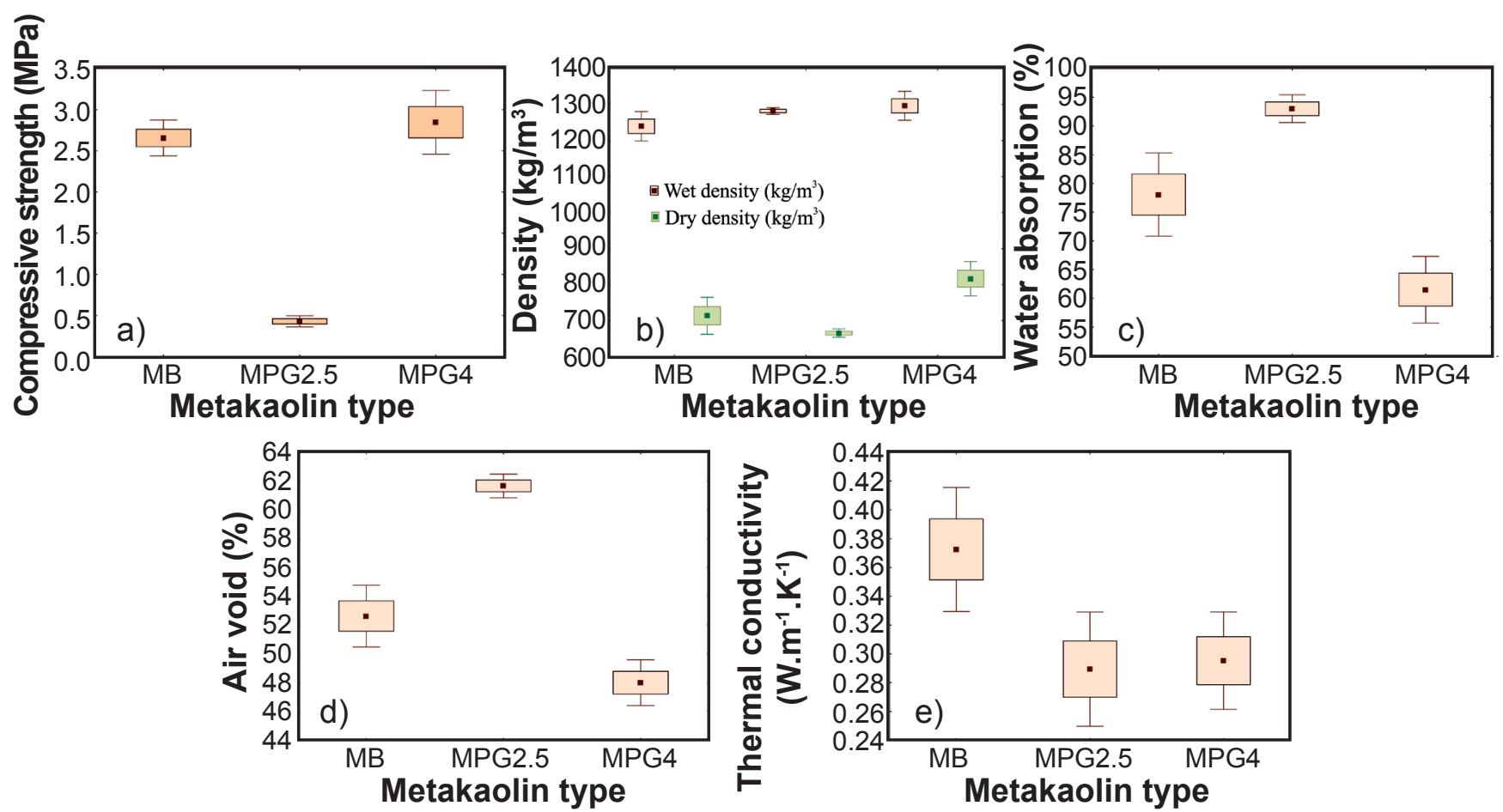

Figure 6: Results of compressive strength (a), dry and saturated densities (b), water absorption (c), air void (d), and thermal conductivity (e) of geopolymers prepared with different precursors. 
Table III - Comparison between properties for different materials.

\begin{tabular}{cccc}
\hline Property & Foamed geopolymer & Foamed concrete [53] & Autoclaved concrete [53] \\
\hline Compressive strength $(\mathrm{MPa})$ & 0.36 to 3.23 & 0.44 to 0.73 & 1.56 to 1.99 \\
Dry bulk density $\left(\mathrm{kg} / \mathrm{m}^{3}\right)$ & 619.4 to 864.2 & 530.5 to 597.8 & 434.8 to 487.2 \\
Wet bulk density $\left(\mathrm{kg} / \mathrm{m}^{3}\right)$ & 1176.5 to 1364.3 & 976.5 to 1107.3 & 909.9 to 985.1 \\
Water absorption $(\%)$ & 55.7 to 95.4 & 84.7 to 89.8 & 83.6 to 94.9 \\
Air void $(\%)$ & 46.4 to 62.5 & 41.2 to 46.8 & 46.2 to 53.3 \\
Thermal conductivity $\left(\mathrm{W} \cdot \mathrm{m}^{-1} \cdot \mathrm{K}^{-1}\right)$ & 0.22 to 0.42 & 0.23 to 0.28 & 0.17 to 0.20 \\
\hline
\end{tabular}

precursor, thereby generating a porous geopolymeric paste. In Fig. 6e, the thermal conductivity in relation to the different types of metakaolin can be observed. The greater number of pores observed in the specimens of paste made with the precursor MPG2.5 resulted in a lower thermal conductivity, with an average value of $0.29 \mathrm{~W} /(\mathrm{m} . \mathrm{K})$. In samples with $\mathrm{MB}$, an average thermal conductivity of $0.38 \mathrm{~W} /(\mathrm{m} . \mathrm{K})$ was obtained and, in samples of MPG4, this was approximately $0.30 \mathrm{~W} /(\mathrm{m} \cdot \mathrm{K})$.

Since there are no standards specifying mechanical property limit values for foamed geopolymers, the minimum value required by ASTM C869/C869M-11 [51] of 1.4 $\mathrm{MPa}$ for foam cellular concrete was used to evaluate the compressive strength. It was observed that the specimens of MPG4 and MB can be obtained with compressive strength higher than the minimum value required by this standard. An analysis showed that the sample with the lowest compressive strength and density had the lowest thermal conductivity. This result was in agreement with the results found by Lach et al. [52]. Comparing the results obtained with conventional concrete blocks that use Portland cement (foamed concrete and autoclaved concrete), it was observed that the values of dry and wet bulk densities of geopolymers were higher than the two types of concrete developed with Portland cement; besides, the maximum value of compressive strength was higher for foamed geopolymer. Regarding thermal conductivity, autoclaved concrete still shows better results when compared to foamed geopolymer, as values less than $0.2 \mathrm{~W} /(\mathrm{m} . \mathrm{K})$ are obtained. The water absorption and air void values for Portland cement-based concretes are contained in the ranges of values found for foamed geopolymers. These comparisons can be seen in Table III.

The pore size and shape presented were related to the specimens developed with different precursors, since the type of precursor was the factor that had the greatest influence on porosity. In Fig. 7, the macrographs can be seen for the specimens with MB (Fig. 7a), MPG4 (Fig. 7b), and MPG2.5 (Fig. 7c). A uniform distribution of the pores was observed for all specimens. However, the shapes of the pores were different, i.e. the geopolymer made with MPG4 presented regular spherical closed (isolated) pores contributing to less water absorption. The specimens with MPG2.5 presented irregular shape and open (interconnected) pores, thus increasing capillarity and, consequently, increasing water absorption. The MB specimens, on the other hand, presented an intermediate pore shape between MPG4 and MPG2.5, namely, irregular shape and regular spherical shape. It was also noticed that the less reactive material, in the case of geopolymer with MPG2.5, had an average porosity of approximately $62 \%$, compared to average porosities of approximately $52 \%$ for MB and $48 \%$ for MPG4 based geopolymers. Fig. 8 a shows the graph of the cumulative frequency distributions of the pore size for geopolymers developed with different types of precursors. Also, in Fig. 8b, the binary images used to analyze the sizes of the pores, with respective values of $\mathrm{D} 10, \mathrm{D} 50$, and D90 can be seen. The results indicated that the pore sizes, considered perfect circles, varied from 10 to $1340 \mu \mathrm{m}$. Based on D10, D50, and D90 values (used to represent the mean and particle size range), it can be said in practical terms that the pore diameters remained constant for the different types of precursors for D10. For D50 and D90, small increases in pore diameters were observed, i.e. the geopolymers with MPG2.5 had a larger diameter than the geopolymers with MPG4, which in turn had a larger pore diameter than the geopolymers developed with MB (pore size: MPG2.5>MPG4>MB).

Alkali content effect: Fig. 9 shows the graphs that relate
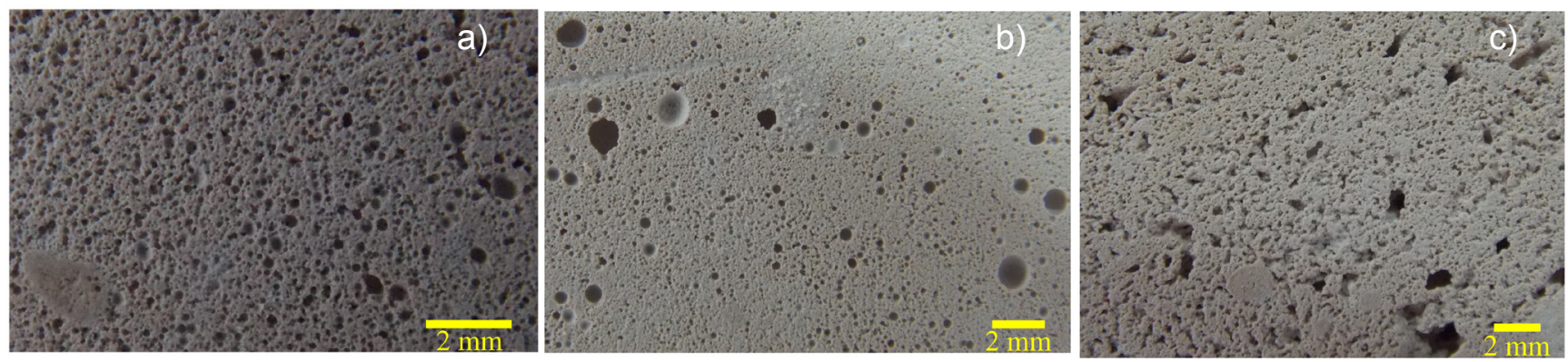

Figure 7: Macrographs showing pores in the geopolymer specimens prepared with: a) MB; b) MPG4; and c) MPG2.5. 


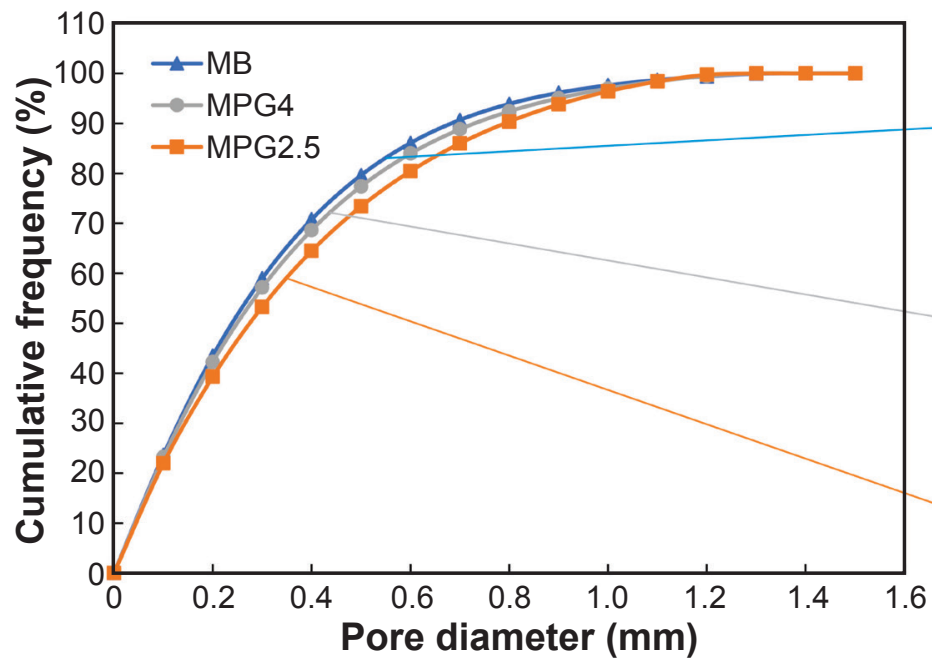

a)

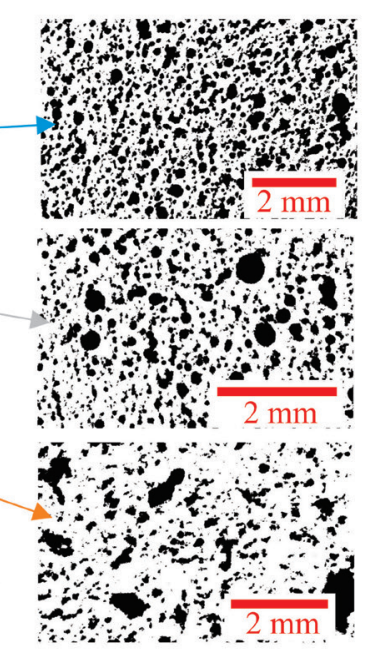

b)

\author{
$M B-D 10=43 \mu \mathrm{m}$ \\ $M B-D 50=239 \mu \mathrm{m}$ \\ $\mathrm{MB}-\mathrm{D} 90=683 \mu \mathrm{m}$ \\ MPG4 - D10 $=43 \mu \mathrm{m}$ \\ MPG4 - D50 $=249 \mu \mathrm{m}$ \\ MPG4 - D90 $=730 \mu \mathrm{m}$ \\ MPG2.5 - D10 $=42 \mu \mathrm{m}$ \\ $M P G 2.5-D 50=275 \mu \mathrm{m}$ \\ $\mathrm{MPG} 2.5-\mathrm{D} 90=791 \mu \mathrm{m}$
}

Figure 8: Cumulative frequency distribution curves of average pore diameter in geopolymers for different precursor types (a), and typical binary images for different mixes (b).

the compressive strength, densities (saturated and dry), water absorption, air void, and thermal conductivity with the alkali content, where the point is the median value, the box the standard deviation, and the whiskers the $95 \%$ confidence interval. When analyzing the variation in compressive strength (Fig.9a), it was observed that on average the increase in the alkali content generated an increase in compressive strength, as well as the increases in the dry and saturated densities (Fig. 9b). Regarding the relationship between the alkali content and water absorption (Fig. 9c), it was identified that a reduction in alkalis increased the porosity of the foamed geopolymeric mortar. Regarding the relationship between the alkali content and the air void (Fig. 9d), it was evident that the reduction of alkalis increased the porosity of the foamed geopolymeric mortar. This factor had a high contribution on the air void value of the pastes evaluated and the increase in the alkali content from $15 \%$ to $20 \%$ reduced the average value from $56 \%$ to $52 \%$. Little variation was observed on thermal conductivity when the alkali content in the foamed geopolymeric paste was changed (Fig. 9e). In general, the alkali content in the mixture had little influence on this factor, with the averages ranging between 0.32 and $0.33 \mathrm{~W} /(\mathrm{m} . \mathrm{K})$ for the alkali content of $15 \%$ and $20 \%$, respectively. The variations found in the properties of the geopolymers in relation to the increase in the alkali content were possibly due to the auxiliary increase in breaking the bonds $\mathrm{Si}-\mathrm{O}-\mathrm{Si}$, Si-O-Al, and $\mathrm{Al}-\mathrm{O}-\mathrm{Al}$, which were present in the vitreous phase of metakaolin that condensed after forming $\mathrm{Si}-\mathrm{OH}$ and $\mathrm{Al}-\mathrm{OH}$ groups, thereby generating the aluminosilicate gel [54]. In addition, the increase in the alkali content was responsible for dissolving the solid part of the precursor, thereby generating a foamed geopolymeric paste with less porosity and closed pores $[28,55]$.

Silica modulus: the graphs in Fig. 10 show the variation of the parameters studied according to the silica modulus. It was verified that the geopolymeric pastes with silica modulus of 0.5 presented average compression strength higher than the geopolymer pastes that were developed with the silica modulus of 1.0. The silica modulus (SM) is represented by the ratio of silicon oxide $\left(\mathrm{SiO}_{2}\right)$ and the sum of aluminum $\left(\mathrm{Al}_{2} \mathrm{O}_{3}\right)$ and iron $\left(\mathrm{Fe}_{2} \mathrm{O}_{3}\right)$ oxides. This relationship is closely related to the development of the liquid phase. This modulus expresses a correlation between components with high hydraulic activity and the liquid phase. Also, it can be said that there is no single ideal value for the silica modulus since for each precursor there is an optimal value, which is governed fundamentally by the nature and granulometry of the 'siliceous' components [28]. Regarding its interference in the strength values obtained for the samples of geopolymeric pastes, the increase of the silica modulus contributed to the formation of more compact pastes, thus giving the geopolymeric paste better mechanical properties. However, for foamed geopolymeric pastes, the increase in the silica modulus resulted in a more voluminous paste. In other words, this increase provided less degradation of the foam bubbles, thus forming a less dense paste with a greater and, consequently, less resistance to compression. This effect may be related to the decrease in the degree of geopolymer reaction when the silica modulus is increased $[22,56]$. The relationship between dry and saturated densities with the silica modulus can be seen in Fig. 10b. The densities, dry and saturated, decreased on increasing the silica modulus. The relationships between water absorption and air void with the silica modulus are shown in Figs. 10c and 10d, respectively, where it can be identified that the addition of soluble silica resulted in higher water absorption and greater porosity (air void). Fig. $10 \mathrm{e}$ shows the graph of thermal conductivity based on the silica modulus. It was seen that the silica modulus had a great influence on thermal conductivity, with the value of 0.5 resulting in an average conductivity of $0.39 \mathrm{~W} /(\mathrm{m} . \mathrm{K})$. Geopolymers developed with a silica modulus of $1.0 \mathrm{had}$ a 

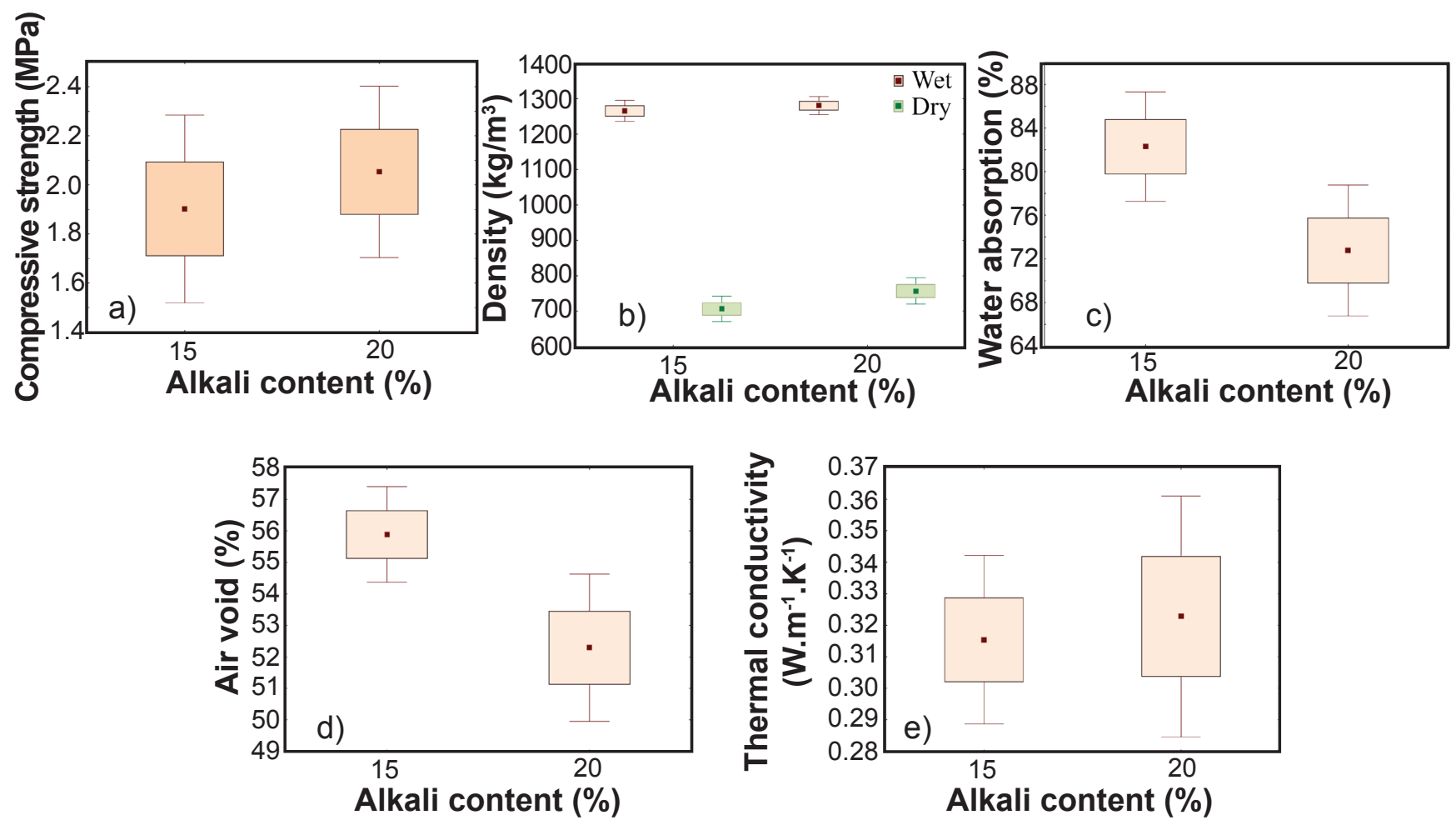

Figure 9: Results of compressive strength (a), dry and saturated densities (b), water absorption (c), air void (d), and thermal conductivity (e) of geopolymers prepared with different alkali contents.
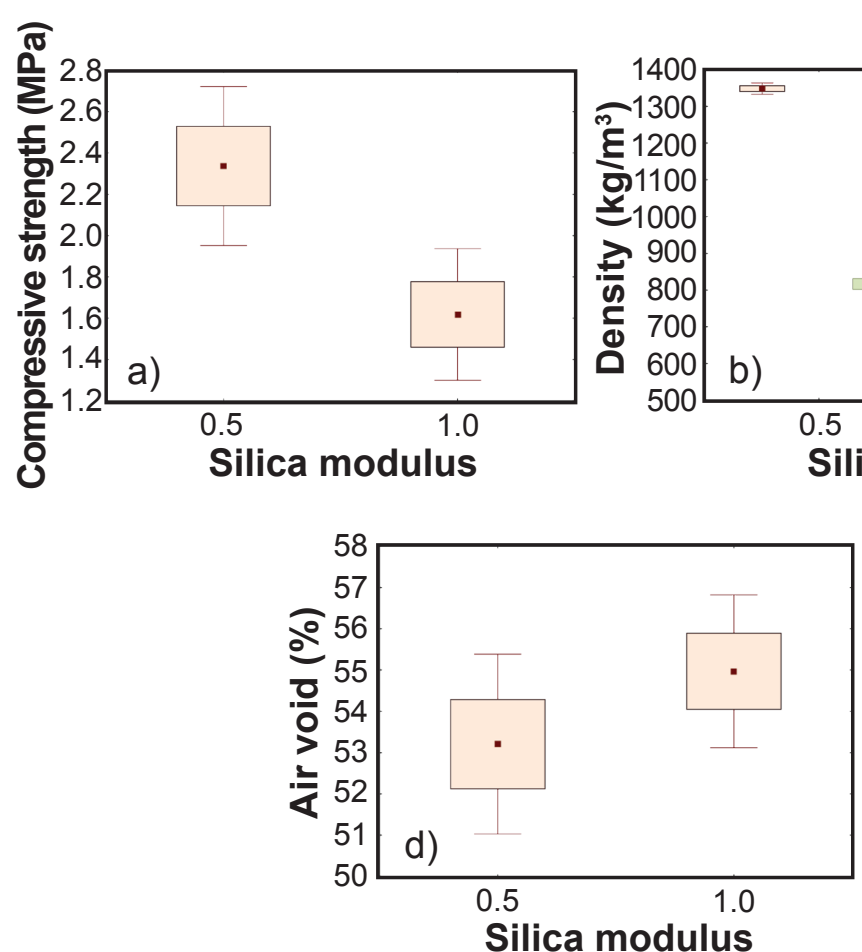
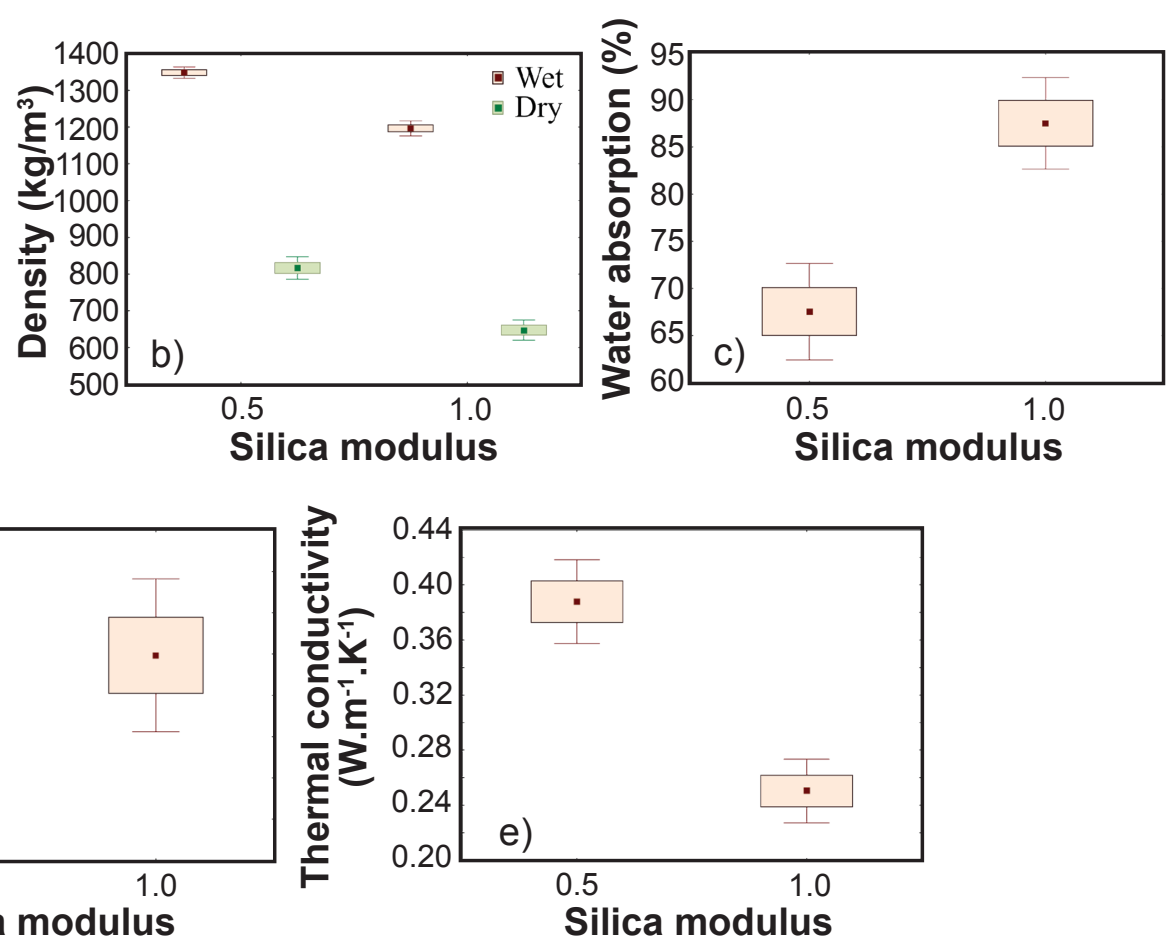

Figure 10: Results of compressive strength (a), dry and saturated densities (b), water absorption (c), air void (d), and thermal conductivity (e) of geopolymers prepared with different silica moduli.

reduction in thermal conductivity to $0.25 \mathrm{~W} /(\mathrm{m} . \mathrm{K})$.

Foam content: in order to identify the interaction of the analyzed parameters with the foam content, the graphs in
Fig. 11 are presented. Observing the graph of compressive strength (Fig. 11a), it was noticed that increasing the amount of foam resulted in the decrease of resistance to 

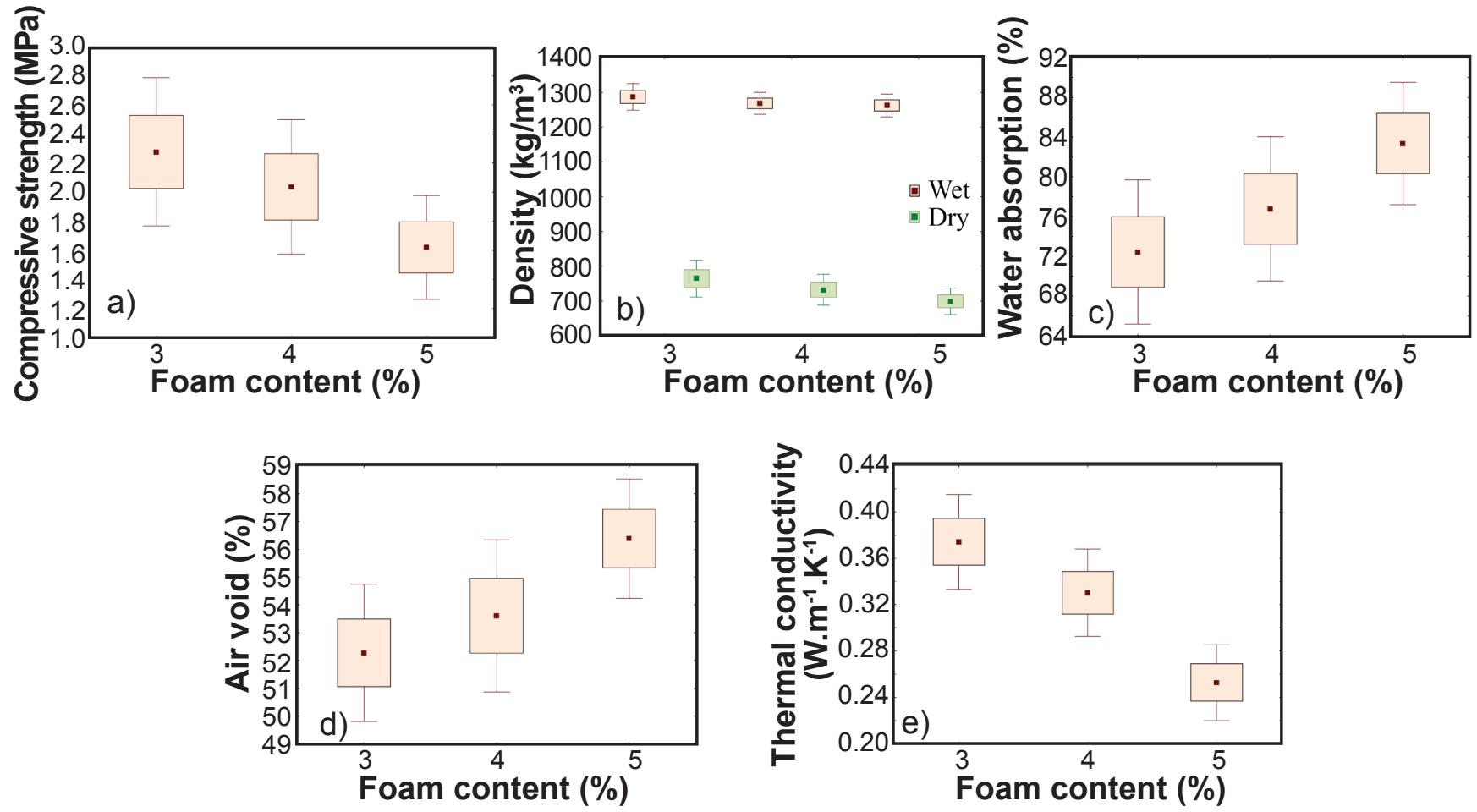

Figure 11: Results of compressive strength (a), dry and saturated densities (b), water absorption (c), air void (d), and thermal conductivity (e) of geopolymers prepared with different foam contents (percentage over total mass).

compression, which was due to the incorporation of air, which formed the pores in the structure, thereby decreasing density and consequently the compressive strength. Fig. 11b shows the relationship between dry and saturated densities with foam content. As expected, the smallest amount of foam resulted in the highest average densities. When the addition of foam was lower, the bubbles of incorporated air grouped because of dehydration, thus resulting in larger bubbles. Density variations can also occur with the collapse of the bubbles due to the reduction of the hydro-lipophilic film, thus making the bubbles less resistant. According to Cilla [57], with the increase in the concentration of the foaming agent, its adsorption at the gas/liquid interface is favored and the surface tension decreases, thus promoting the formation of foam and consequently decrease the density of the specimens by increasing the concentration of foam. Regarding the water absorption (Fig. 11c), the greater the amount of foam, the greater the water absorption. This phenomenon occurred due to the increase in the amount of total voids and the connectivity between the pores (capillarity). Moreover, it is possible to verify in Fig. 11d that the increase of the foam content favored the air void in the foamed geopolymeric pastes. The specimens made with the addition of $5 \%$ of foam had an average air void of $57 \%$, while the specimens with the addition of $4 \%$ of foam resulted in an average air void of 54\% and the addition of 3\% of foam resulted in an average void rate of $52 \%$. This increase in the air void can be attributed to the increase in the interconnected porosity (open pores), i.e., there was a greater connection between the pores of the specimens, when the foam content was increased
[57]. Fig. 11e shows the graph of thermal conductivity based on the amount of foam. As expected, increasing the amount of foam in the geopolymeric paste, the thermal conductivity decreased, because of the greater amount of foam, the greater number of pores, and, consequently, the greater amount of air, which, inside the pores, behaves as a thermal insulator.

ANOVA for the properties of the foamed geopolymers: the compressive strength is essential, as it serves as a parameter to understand the quality of the material and to evaluate the polymerization, which is directly related to the strength, i.e. the mechanical performance is affected by factors such as the $\mathrm{SiO}_{2} / \mathrm{Al}_{2} \mathrm{O}_{3}$ ratio, the nature of the solid, the concentration of the activating solution, the solid/liquid ratio (water and activator) and the amount of water $[36,37,58]$. Table IV shows the results of the analysis of variance for compressive strength. It was stated that the precursor, the alkali content, the silica modulus, and the foam content had a significant influence, as well as the interaction between the factors, except for the interactions between the alkali content and foam content, the precursor, alkali content, and foam content, and the alkali content, silica modulus, and foam content, with 95\% confidence or higher. It was also observed that the type of precursor was the factor that most influenced the compressive strength, with a contribution of $67.9 \%$. Furthermore, it was seen that the interaction between the precursor, alkali content, and silica modulus also had a high contribution to the compressive strength, which corresponded to the difference in the behavior of a given factor at different levels of the other factor.

Tables V and VI present the results of the analysis of 
variance for saturated density and dry density, respectively. For these properties, all factors and all interactions between them had a significant influence (significance of $95 \%$ or more). It was observed that the amount of foam, despite having a significant influence, was not the factor that most influenced the density of the material. This observation

Table IV - Results of ANOVA for compressive strength.

\begin{tabular}{ccccccc}
\hline Factor & $\begin{array}{c}\text { Sum of } \\
\text { squares }\end{array}$ & $\begin{array}{c}\text { Degree of } \\
\text { freedom }\end{array}$ & $\begin{array}{c}\text { Mean of } \\
\text { squares }\end{array}$ & F-value & p-value & $\begin{array}{c}\text { Contribution } \\
(\%)\end{array}$ \\
\hline Metakaolin type (MT) & 130.127 & 2 & 65.064 & 1385.72 & 0.0000 & 67.9 \\
\% alkali (A) & 0.616 & 1 & 0.616 & 13.13 & 0.0005 & 0.3 \\
Silica modulus (SM) & 13.954 & 1 & 13.954 & 297.18 & 0.0000 & 7.3 \\
Foam content (FC) & 7.968 & 2 & 3.984 & 84.85 & 0.0000 & 4.2 \\
MT*A & 0.516 & 2 & 0.258 & 5.50 & 0.0060 & 0.3 \\
MT*SM & 6.728 & 2 & 3.364 & 71.64 & 0.0000 & 3.5 \\
A*SM & 3.542 & 1 & 3.542 & 75.45 & 0.0000 & 1.8 \\
MT*FC & 3.292 & 4 & 0.823 & 17.53 & 0.0000 & 1.7 \\
A*FC & 0.006 & 2 & 0.003 & 0.06 & 0.9391 & 0.0 \\
SM*FC & 0.477 & 2 & 0.239 & 5.08 & 0.0086 & 0.2 \\
MT*A*SM & 17.852 & 2 & 8.926 & 190.11 & 0.0000 & 9.3 \\
MT*A*FC & 0.099 & 4 & 0.025 & 0.53 & 0.7142 & 0.1 \\
MT*SM*FC & 0.686 & 4 & 0.172 & 3.65 & 0.0091 & 0.4 \\
A*SM*FC & 0.220 & 2 & 0.110 & 2.34 & 0.1035 & 0.1 \\
MT*A*SM*FC & 2.194 & 4 & 0.548 & 11.68 & 0.0000 & 1.1 \\
Error & 3.381 & 72 & 0.047 & & & 1.8 \\
Total & 191.659 & & & & & 100.0 \\
\hline
\end{tabular}

* interaction between factors.

Table V - Results of ANOVA for wet bulk density.

\begin{tabular}{ccccccc}
\hline Factor & $\begin{array}{c}\text { Sum of } \\
\text { squares }\end{array}$ & $\begin{array}{c}\text { Degree of } \\
\text { freedom }\end{array}$ & $\begin{array}{c}\text { Mean of } \\
\text { squares }\end{array}$ & F-value & p-value & $\begin{array}{c}\text { Contribution } \\
(\%)\end{array}$ \\
\hline Metakaolin type (MT) & 62254 & 2 & 31127 & 91.1 & 0.0000 & 5.7 \\
\% alkali (A) & 5886 & 1 & 5886 & 17.2 & 0.0001 & 0.5 \\
Silica modulus (SM) & 622116 & 1 & 622116 & 1819.8 & 0.0000 & 57.0 \\
Foam content (FC) & 11883 & 2 & 5942 & 17.4 & 0.0000 & 1.1 \\
MT*A & 8750 & 2 & 4375 & 12.8 & 0.0000 & 0.8 \\
MT*SM & 149693 & 2 & 74847 & 218.9 & 0.0000 & 13.7 \\
A*SM & 27222 & 1 & 27222 & 79.6 & 0.0000 & 2.5 \\
MT*FC & 5645 & 4 & 1411 & 4.1 & 0.0046 & 0.5 \\
A*FC & 9820 & 2 & 4910 & 14.4 & 0.0000 & 0.9 \\
SM*FC & 9675 & 2 & 4838 & 14.2 & 0.0000 & 0.9 \\
MT*A*SM & 117426 & 2 & 58713 & 171.7 & 0.0000 & 10.8 \\
MT*A*FC & 3733 & 4 & 933 & 2.7 & 0.0356 & 0.3 \\
MT*SM*FC & 18149 & 4 & 4537 & 13.3 & 0.0000 & 1.7 \\
A*SM*FC & 10104 & 2 & 5052 & 14.8 & 0.0000 & 0.9 \\
MT*A*SM*FC & 4779 & 4 & 1195 & 3.5 & 0.0115 & 0.4 \\
Error & 24614 & 72 & 342 & & & 2.3 \\
Total & 1091751 & & & & & 100.0 \\
\hline
\end{tabular}

* interaction between factors. 
Table VI - Results of ANOVA for dry bulk density.

\begin{tabular}{ccccccc}
\hline Factor & $\begin{array}{c}\text { Sum of } \\
\text { squares }\end{array}$ & $\begin{array}{c}\text { Degree of } \\
\text { freedom }\end{array}$ & $\begin{array}{c}\text { Mean of } \\
\text { squares }\end{array}$ & F-value & p-value & $\begin{array}{c}\text { Contribution } \\
(\%)\end{array}$ \\
\hline Metakaolin type (MT) & 429153 & 2 & 214576 & 677.7 & 0.0000 & 21.7 \\
\% alkali (A) & 69507 & 1 & 69507 & 219.5 & 0.0000 & 3.5 \\
Silica modulus (SM) & 774982 & 1 & 774982 & 2447.7 & 0.0000 & 39.2 \\
Foam content (FC) & 77721 & 2 & 38860 & 122.7 & 0.0000 & 3.9 \\
MT*A & 49735 & 2 & 24867 & 78.5 & 0.0000 & 2.5 \\
MT*SM & 237662 & 2 & 118831 & 375.3 & 0.0000 & 12.0 \\
A*SM & 31679 & 1 & 31679 & 100.1 & 0.0000 & 1.6 \\
MT*FC & 18543 & 4 & 4636 & 14.6 & 0.0000 & 0.9 \\
A*FC & 1792 & 2 & 896 & 2.8 & 0.0656 & 0.1 \\
SM*FC & 28275 & 2 & 14137 & 44.7 & 0.0000 & 1.4 \\
MT*A*SM & 179267 & 2 & 89634 & 283.1 & 0.0000 & 9.1 \\
MT*A*FC & 14147 & 4 & 3537 & 11.2 & 0.0000 & 0.7 \\
MT*SM*FC & 15655 & 4 & 3914 & 12.4 & 0.0000 & 0.8 \\
A*SM*FC & 8742 & 2 & 4371 & 13.8 & 0.0000 & 0.4 \\
MT*A*SM*FC & 17514 & 4 & 4379 & 13.8 & 0.0000 & 0.9 \\
Error & 22797 & 72 & 317 & & & 1.2 \\
Total & 1977170 & & & & & 100.0 \\
\hline
\end{tabular}

* interaction between factors.

Table VII - Results of ANOVA for water absorption.

\begin{tabular}{ccccccc}
\hline Factor & $\begin{array}{c}\text { Sum of } \\
\text { squares }\end{array}$ & $\begin{array}{c}\text { Degree of } \\
\text { freedom }\end{array}$ & $\begin{array}{c}\text { Mean of } \\
\text { squares }\end{array}$ & F-value & p-value & $\begin{array}{c}\text { Contribution } \\
(\%)\end{array}$ \\
\hline Metakaolin type (MT) & 17902 & 2 & 8951 & 788.2 & 0.0000 & 38.9 \\
\% alkali (A) & 2446 & 1 & 2446 & 215.4 & 0.0000 & 5.3 \\
Silica modulus (SM) & 10740 & 1 & 10740 & 945.7 & 0.0000 & 23.3 \\
Foam content (FC) & 2174 & 2 & 1087 & 95.7 & 0.0000 & 4.7 \\
MT*A & 1698 & 2 & 849 & 74.8 & 0.0000 & 3.7 \\
MT*SM & 4457 & 2 & 2228 & 196.2 & 0.0000 & 9.7 \\
A*SM & 407 & 1 & 407 & 35.8 & 0.0000 & 0.9 \\
MT*FC & 277 & 4 & 69 & 6.1 & 0.0003 & 0.6 \\
A*FC & 116 & 2 & 58 & 5.1 & 0.0084 & 0.3 \\
SM*FC & 378 & 2 & 189 & 16.6 & 0.0000 & 0.8 \\
MT*A*SM & 2900 & 2 & 1450 & 127.7 & 0.0000 & 6.3 \\
MT*A*FC & 597 & 4 & 149 & 13.1 & 0.0000 & 1.3 \\
MT*SM*FC & 414 & 4 & 103 & 9.1 & 0.0000 & 0.9 \\
A*SM*FC & 257 & 2 & 129 & 11.3 & 0.0001 & 0.6 \\
MT*A*SM*FC & 450 & 4 & 113 & 9.9 & 0.0000 & 1.0 \\
Error & 818 & 72 & 11 & & & 1.8 \\
Total & 46031 & & & & & 100.0 \\
\hline
\end{tabular}

* interaction between factors.

was due to the fact that the greater the amount of foam, the greater the air void and the lower the density of the material. However, the increase in the amount of soluble silica in the foamed geopolymeric system contributed to the 
Table VIII - Results of ANOVA for air void.

\begin{tabular}{ccccccc}
\hline Factor & $\begin{array}{c}\text { Sum of } \\
\text { squares }\end{array}$ & $\begin{array}{c}\text { Degree of } \\
\text { freedom }\end{array}$ & $\begin{array}{c}\text { Mean of } \\
\text { squares }\end{array}$ & F-value & p-value & $\begin{array}{c}\text { Contribution } \\
(\%)\end{array}$ \\
\hline Metakaolin type (MT) & 3486.9 & 2 & 1743.4 & 408.5 & 0.0000 & 59.3 \\
\% alkali (A) & 349.4 & 1 & 349.4 & 81.9 & 0.0000 & 5.9 \\
Silica modulus (SM) & 83.9 & 1 & 83.9 & 19.7 & 0.0000 & 1.4 \\
Foam content (FC) & 316.5 & 2 & 158.2 & 37.1 & 0.0000 & 5.4 \\
MT*A & 174.4 & 2 & 87.2 & 20.4 & 0.0000 & 3.0 \\
MT*SM & 214.3 & 2 & 107.2 & 25.1 & 0.0000 & 3.6 \\
A*SM & 1.7 & 1 & 1.7 & 0.4 & 0.5313 & 0.0 \\
MT*FC & 71.7 & 4 & 17.9 & 4.2 & 0.0041 & 1.2 \\
A*FC & 104.6 & 2 & 52.3 & 12.3 & 0.0000 & 1.8 \\
SM*FC & 116.9 & 2 & 58.5 & 13.7 & 0.0000 & 2.0 \\
MT*A*SM & 162.3 & 2 & 81.2 & 19.0 & 0.0000 & 2.8 \\
MT*A*FC & 140.5 & 4 & 35.1 & 8.2 & 0.0000 & 2.4 \\
MT*SM*FC & 164.4 & 4 & 41.1 & 9.6 & 0.0000 & 2.8 \\
A*SM*FC & 60.3 & 2 & 30.1 & 7.1 & 0.0016 & 1.0 \\
MT*A*SM*FC & 127.3 & 4 & 31.8 & 7.5 & 0.0000 & 2.2 \\
Error & 307.3 & 72 & 4.3 & & & 5.2 \\
Total & 5882.4 & & & & & 100.0 \\
\hline
\end{tabular}

* interaction between factors.

Table IX - Results of ANOVA for thermal conductivity.

\begin{tabular}{ccccccc}
\hline Factor & $\begin{array}{c}\text { Sum of } \\
\text { squares }\end{array}$ & $\begin{array}{c}\text { Degree of } \\
\text { freedom }\end{array}$ & $\begin{array}{c}\text { Mean of } \\
\text { squares }\end{array}$ & F-value & P-value & $\begin{array}{c}\text { Contribution } \\
(\%)\end{array}$ \\
\hline Metakaolin type (MT) & 0.155 & 2 & 0.077 & 149.22 & 0.0000 & 10.0 \\
\% alkali (A) & 0.001 & 1 & 0.001 & 2.86 & 0.0953 & 0.1 \\
Silica modulus (SM) & 0.510 & 1 & 0.510 & 983.15 & 0.0000 & 32.9 \\
Foam content (FC) & 0.272 & 2 & 0.136 & 262.30 & 0.0000 & 17.5 \\
MT*A & 0.083 & 2 & 0.042 & 80.27 & 0.0000 & 5.4 \\
MT*SM & 0.041 & 2 & 0.021 & 39.84 & 0.0000 & 2.7 \\
A*SM & 0.107 & 1 & 0.107 & 206.43 & 0.0000 & 6.9 \\
MT*FC & 0.029 & 4 & 0.007 & 13.88 & 0.0000 & 1.9 \\
A*FC & 0.027 & 2 & 0.013 & 25.95 & 0.0000 & 1.7 \\
SM*FC & 0.002 & 2 & 0.001 & 1.56 & 0.2181 & 0.1 \\
MT*A*SM & 0.095 & 2 & 0.048 & 91.73 & 0.0000 & 6.1 \\
MT*A*FC & 0.033 & 4 & 0.008 & 15.67 & 0.0000 & 2.1 \\
MT*SM*FC & 0.001 & 4 & 0.000 & 0.37 & 0.8264 & 0.1 \\
A*SM*FC & 0.070 & 2 & 0.035 & 67.59 & 0.0000 & 4.5 \\
MT*A*SM*FC & 0.089 & 4 & 0.022 & 42.88 & 0.0000 & 5.7 \\
Error & 0.037 & 72 & 0.001 & & & 2.4 \\
Total & 1.552 & & & & & 100.0 \\
\hline
\end{tabular}

* interaction between factors.

maintenance and coalescence of the foam, i.e. the bubbles formed by the foaming agent merged, thus forming larger pores. This explained the greater contribution $(57 \%)$ of the silica modulus to the density of the material. This fact was also shown by Ducman and Korat [22]. Table VII presents the results of the analysis of variance for water absorption 
with 95\% confidence. It was observed that, just as for dry and saturated densities, it was not the amount of foam that had the greatest influence on water absorption, but the type of precursor used, with a $38.9 \%$ contribution. The silica modulus contributed with $23.3 \%$, the alkali content contributed with $5.3 \%$, and the foam content contributed with 4.7\%. All interactions showed a significant influence, but the interactions between the precursor and silica modulus, and the precursor, silica modulus, and alkali content stand out.

Table VIII presents the results of the analysis of variance for air void. It was stated with $95 \%$ confidence that the precursor, the alkali content, the foam content, and the silica modulus had a significant influence on the number of pores present in the specimens of the foamed geopolymeric paste. The factor that had the greatest influence on the air void was the metakaolin (precursor), with a 59.3\% contribution. It was noticed that the alkali content and the foam content, in addition to the silica modulus, acting individually had a much less significant contribution $(5.9 \%, 5.4 \%$, and $1.4 \%$, respectively) on the number of pores. Finally, the results of the analysis of variance for thermal conductivity are presented in Table IX, in which it can be seen that there was no evidence of the influence of the alkali content on thermal conductivity since the p-value was higher than 0.05 . The factor that had the greatest influence on thermal conductivity was the silica modulus, with a $32.9 \%$ contribution, and the foam content, with a contribution of $17.5 \%$.

\section{CONCLUSIONS}

Based on the results obtained, it was concluded that the formation of a foamed geopolymeric paste is a viable alternative to producing foamed blocks with Portland cement, as it can be more sustainable material because less energy is required for its production, in addition to the possibility to obtain satisfactory properties compared to conventional cell blocks. Regarding the characterization of metakaolin, it was clear that the degree of amorphism, in addition to the $\mathrm{SiO}_{2} / \mathrm{Al}_{2} \mathrm{O}_{3}$ ratio, is an important factor in the manufacture of geopolymeric pastes, since they are directly linked to reactivity. In this study, the sample with the highest degree of amorphism promoted the highest strength, followed by the samples with the highest $\mathrm{Si} / \mathrm{Al}$ ratio. Therefore, the chemical composition of the precursor is important in the geopolymerization process. From the spectroscopic point of view, it was possible to observe the synthesis of the geopolymer for all developed pastes, since the FTIR bands close to $1000 \mathrm{~cm}^{-1}$ were detected. Another important factor when evaluating the samples was the dosage of the activators. In this regard, it was concluded that the samples with the silica modulus of 1.0 gave more satisfactory results in terms of density (lighter materials), and lower thermal conductivity; however, they presented lower compressive strengths. The compressive strength was inversely proportional to the total porosity. The dry density and the saturated density decreased with the increase of the silica modulus and the foam content in the structure of the specimens, the latter related to the increase of the open porosity with the increase of the amount of foaming agent in the composition. The air void and water absorption were strongly influenced by the metakaolin type, i.e. the metakaolin calcined for $4 \mathrm{~h}$ (MPG4) was the precursor that had less water absorption and fewer air voids. The type of precursor, mainly due to the content of silica available for reaction, affected the compressive strength, water absorption, and void content. Also, it was verified that the silica modulus affected the conductivity and density of the geopolymer. When evaluating the effects of the factors, it was observed that the type of precursor and the silica modulus were the factors that most influenced the material properties. Thus, it was concluded that the best foamed geopolymer was synthesized with the precursor MPG4, silica modulus of 1.0, and $15 \%$ of alkalis. In addition, the amount of foam can be added to regulate properties, that is, the amount of foam can be added to decrease densities and thermal conductivity.

\section{ACKNOWLEDGMENT}

The authors would like to thank Fundação Meridional for the grant of financial support.

\section{REFERENCES}

[1] Z. Zhang, J.L. Provis, A. Reid, H. Wang, Constr. Build. Mater. 56 (2014) 113.

[2] P.K. Mehta, P.J. Monteiro, Concrete: microstructure, properties and materials, $4^{\text {th }}$ ed., McGraw-Hill (2013).

[3] A. Passuello, E.D. Rodríguez, E. Hirt, M. Longhi, S.A. Bernal, J.L. Provis, A.P. Kirchheim, J. Clean. Prod. 166 (2017) 680.

[4] Z. Zhang, J.L. Provis, A. Reid, H. Wang, Cem. Concr. Compos. 62 (2015) 97.

[5] J. Davidovits, J. Therm. Anal. Calorim. 37, 8 (1991) 1633.

[6] J. Davidovits, in Geopolymer 2002 Conf., Melbourne (2002).

[7] J.L. Bell, P.E. Driemeyer, W.M. Kriven, J. Am. Ceram. Soc. 92, 1 (2009) 1.

[8] J. Davidovits, in Proc. 41 ${ }^{\text {st }}$ Int. Conf. Adv. Ceram. Compos., Ceram. Eng. Sci. Proc., John Wiley Sons (2018) 201.

[9] P. Duxson, A. Fernández-Jiménez, J.L. Provis, G.C. Lukey, A. Palomo, J.S. Van Deventer, J. Mater. Sci. 42, 9 (2007) 2917.

[10] N. Ranjbar, M. Zhang, Cem. Concr. Compos. 107 (2020) 103498.

[11] S. Samal, M. Kolinova, H. Rahier, G. Dal Poggetto, I. Blanco, Appl. Sci. 9, 3 (2019) 516.

[12] A.T. Akono, S. Koric, W.M. Kriven, Cem. Concr. Compos. 104 (2019) 103361.

[13] E.M. Kumar, K. Ramamurthy, Constr. Build. Mater. 156 (2017) 1137.

[14] S. Fu, P. He, M. Wang, M. Wang, R. Wang, J. Yuan, D. Jia, J. Cui, J. Eur. Ceram. Soc. 39, 2-3 (2019) 563. 
[15] T. Ai, F.-H. Hong, Y.-N. Kang, H.-R. Zhang, X. Yan, Materials 12, 3 (2019) 461.

[16] K. Ikeda, K. Onikura, Y. Nakamura, S. Vedanand, J. Am. Ceram. Soc. 84, 8 (2001) 1717.

[17] A.A. Siyal, M.R. Shamsuddin, N.E. Rabat, M. Zulfiqar, Z. Man, A. Low, J. Clean. Prod. 229 (2019) 232.

[18] L. Ricciotti, A. Occhicone, A. Petrillo, C. Ferone, R. Cioffi, G. Roviello, J. Clean. Prod. 250 (2020) 119588.

[19] R.M. Novais, R.C. Pullar, J.A. Labrincha, Progr. Mater. Sci. 109 (2020) 100621.

[20] R. Kumar, Constr. Build. Mater. 142 (2017) 248.

[21] J.G. Sanjayan, A. Nazari, L. Chen, G.H. Nguyen, Constr. Build. Mater. 79 (2015) 236.

[22] V. Ducman, L. Korat, Mater. Charact. 113 (2016) 207.

[23] P. Hlaváček, V. Šmilauer, F. Škvára, L. Kopecký, R. Šulc, J. Eur. Ceram. Soc. 35, 2 (2015) 703.

[24] G. Masi, W.D. Rickard, L. Vickers, M.C. Bignozzi, A. Van Riessen, Ceram. Int. 40, 9 (2014) 13891.

[25] Z. Su, W. Hou, Z. Sun, W. Lv, Materials 13, 18 (2020) 4059.

[26] V. Phavongkham, S. Wattanasiriwech, T.-W. Cheng, D. Wattanasiriwech, Constr. Build. Mater. 243 (2020) 118282.

[27] M.M.B. Abdullah, K. Hussin, M. Bnhussain, K.N. Ismail, Z. Yahya, R. Abdul Razak, Inter. J. Molec. Sci. 13, 6 (2012) 7186.

[28] M.A. Longhi, "Álcali-ativação de lodo de caulim calcinado e cinza pesada com ativadores convencionais e silicato de sódio alternativo", M.Sc. Diss., UFRGS, Brazil (2015).

[29] K. Komnitsas, D. Zaharaki, Miner. Eng. 2014 (2007) 1261.

[30] C. Carpinoa, R. Brunoa, N. Arcuri, Energy Procedia 133 (2017) 16.

[31] M. García-Maté, I. Santacruz, A. Cuesta, L. LeónReina, M.A. Aranda, I. Baco, V. Morin, G. Walenta, E. Gartner, A.G. De La Torre, Adv. Cem. Res. 27, 7 (2015) 417. [32] P.M. Suherman, A. Van Riessen, B. O'Connor, D. Li, D. Bolton, H. Fairhurst, Powder Diffr. 17, 3 (2002) 178.

[33] ABNT NBR 7215, "Cimento Portland: determinação da resistência à compressão", Ass. Bras. Norm. Técn., Rio Janeiro (1996).

[34] ABNT NBR 9778, “Argamassa e concreto endurecidos: determinação da absorção de água, índice de vazios e massa específica”, Ass. Bras. Norm. Técn., Rio Janeiro (2009).

[35] EN BS 480-11, "Admixtures for concrete, mortar and grout-test methods-part 11: determination of air void characteristics in hardened concrete", British Standards, London (2005).

[36] R. Santa, J. Nones, H. Riella, N. Kuhnen, Blucher Chem. Eng. Proceed. 1, 2 (2015) 9290.
[37] C. Livi, "Desenvolvimento de pasta de geopolímeros a base de cinza volante e hidróxido de sódio", M.Sc. Diss., UFSC, Brazil (2013).

[38] G. Grazzini, C. Balocco, IJER 19 (1995) 8.

[39] M.M. Akiyoshi, A.P. da Silva, M.G. da Silva, V.C. Pandolfelli, Cerâmica 47, 301 (2001) 19.

[40] W.N. dos Santos, Cerâmica 48, 306 (2002) 86.

[41] A. Franco, Appl. Therm. Eng. 27, 14-15 (2007) 2495.

[42] H.M. Sacht, J.A. Rossignolo, W.N. Santos, Matéria 15, 1 (2010) 31.

[43] R.T. Lermen, P. Favaretto, R.D.A. Silva, G.E.N. Hidalgo, R. Tubino, F. Tiecher, Appl. Sci. 9, 15 (2019) 2998. [44] M.A. Longhi, B. Walkley, E.D. Rodriguez, A.P. Kirchheim, Z. Zhang, H. Wang, Compos. B Eng. 176 (2019) 107172.

[45] D.C. Montgomery, Design and analysis of experiments, John Wiley Sons (2017).

[46] Z.G. Ralli, S.J. Pantazopoulou, Int. J. Struct. Integr. (in print).

[47] K. Juengsuwattananon, F. Winnefeld, P. Chindaprasirt, K. Pimraksa, Constr. Build. Mater. 226 (2019) 406.

[48] P.H. Apolonio, J.S. Lima, E.P. Marinho, A.C.V. Nobrega, J.C.O. Freitas, A.E. Martinelli, Cerâmica 66, 378 (2020) 172.

[49] A.G. de S. Azevedo, K. Strecker, C.T. Lombardi, Cerâmica 64, 371 (2018) 388.

[50] A. Nazari, J.G. Sanjayan, Handbook of low carbon concrete, Butterworth-Heinemann (2017).

[51] ASTM C869/C869M-11, "Standard specification for foaming agents used in making preformed foam for cellular concrete", Am. Soc. Test. Mater., USA (2016).

[52] M. Lach, K. Korniejenko, J. Mikuła, Proc. Eng. 151 (2016) 410.

[53] R.T. Lermen, D.D. dos Santos Neto, L.N. de Oliveira, M.P. Secco, A. Dall'agnol, R. de Almeida Silva, R. Arquit, IMED 8, 1 (2019) 111.

[54] A. Fernández-Jiménez, A. Palomo, Cem. Concr. Res. 35, 10 (2005) 1984.

[55] I. García-Lodeiro, A.Y. Palomo, A. Fernández-Jiménez, Cem. Concr. Res. 37, 2 (2007) 175.

[56] R. Firdous, D. Stephan, Constr. Build. Mater. 219 (2019) 31 .

[57] M.S. Cilla, "Highly porous geopolymers: effect of the processing route on the reached properties", Doct. Thesis, UFSCar, Brazil (2015).

[58] A. Palomo, M.T. Blanco-Varela, M. Granizo, F. Puertas, T. Vazquez, M. Grutzeck, Cem. Concr. Res. 29, 7 (1999) 997.

(Rec. 04/05/2020, Rev. 21/09/2020, 24/11/2020, Ac. $12 / 12 / 2020)$ 